\title{
Mental health services in Croatia
}

\section{Sladjana Strkalj Ivezic, ${ }^{1}$ Martina Rojnic Kuzman ${ }^{2}$ and Maja Silobrcic Radic ${ }^{3}$}

1Day Hospital and Community Rehabilitation Centre, Psychiatric Hospital Vrapce, Bolnicka cesta 32, 10090 Zagreb, Croatia,
email sladjana.ivezic@bolnica-vrapce ${ }^{2}$ Department of Psychiatry, Zagreb University Hospital Centre and Zagreb School of Medicine, Croatia ${ }^{3}$ Croatian National Institute of Public Health, Croatia

\begin{abstract}
The Republic of Croatia is in central Europe, on the Mediterranean. A large majority of its 4440000 inhabitants are Croats (89.6\%). The main religion is Roman Catholicism (88\%). Sixteen per cent of the population is aged over 65 years. Croatia was a part of Yugoslavia after the Second World War until 1991, when Croatia declared independence. Following the declaration, Croatia was attacked by the Yugoslav army and by Serbia and suffered a devastating war (1991-95). The transition had consequences for mental health, for example a dramatic rise in the prevalence of post-traumatic stress disorder, especially among soldiers. The majority of soldiers received appropriate psychiatric treatment; there has, however, been an increase in claims motivated by secondary gain, as a result of government policy.

Croatia is a member of the United Nations, the Council of Europe and the North Atlantic Treaty Organization (NATO), and has applied to join the European Union (EU). The EU application is expected to help Croatia shift the focus of its mental health system to community psychiatry.
\end{abstract}

\section{Mental health policy and legislation}

Mental health policy is a construct of the overall health policy, under legislation from the Croatian Ministry of Health and Welfare (CMHW). Currently, two initiatives to define mental health policy are being developed by the $\mathrm{CMHW}$ and the Croatian National Institute of Public Health (CNIPH): the Croatian Alcohol Action Plan (2006) and the National Mental Health Strategy (2009)

The legislation stipulates that mental healthcare is to be provided at primary, secondary and tertiary levels. The primary level comprises general practitioners (GPs), school medicine specialists and mental health professionals in mental health centres and in public health institutes. The secondary level comprises mental health professionals, mainly psychiatrists. The tertiary level - the prevention of mental illness, the promotion of mental health, epidemiology and mental health statistics - is the reponsibility of mental health professionals, the Croatian Institute for Mental Health and the CNIPH, and incorporates the Croatian Psychosis Registry, the Croatian Suicide Registry, and the Croatian National Registry of Treated Psychoactive Drug Addicts.

Other potential creators of the mental health policy, such as mental health professionals and mental service users' organisations, are only marginally involved.
The health budget is covered by social insurance and is tax based. There is no separate budget allocation for mental health, except for drug addictions. Basic healthcare is obligatory for all and is provided by the Croatian Health Insurance Institute. This covers the treatment of all mental illnesses and the cost of antipsychotic drugs. Supplementary and private insurance are possible but uncommon.

\section{Mental health service delivery}

Although GPs are highly accessible, psychiatric diagnoses comprised only $4.8 \%$ of all GP diagnoses in 2007 (CNIPH, 2008) and most service provision for serious mental illness is restricted to psychiatrists (Gater et al, 2005; Rojnic Kuzman et al, 2009a). For years, mental disorders have accounted for $6-7 \%$ of the overall hospital morbidity rate in Croatia. Most of these hospital admissions are for people aged 20-59 years, which makes mental illness one of the leading causes of hospital morbidity in the occupationally active age group and therefore one of the top health priorities (Fig. 1) (CNIPH, 2008).

Patients with a mental illness are largely cared for within hospital; 1 in $4-5$ days of treatment provided in hospitals is for mental disorders (CNIPH, 2008). The therapeutic community movement has promoted the organisation of in-patient programmes and day hospitals. Today, the majority

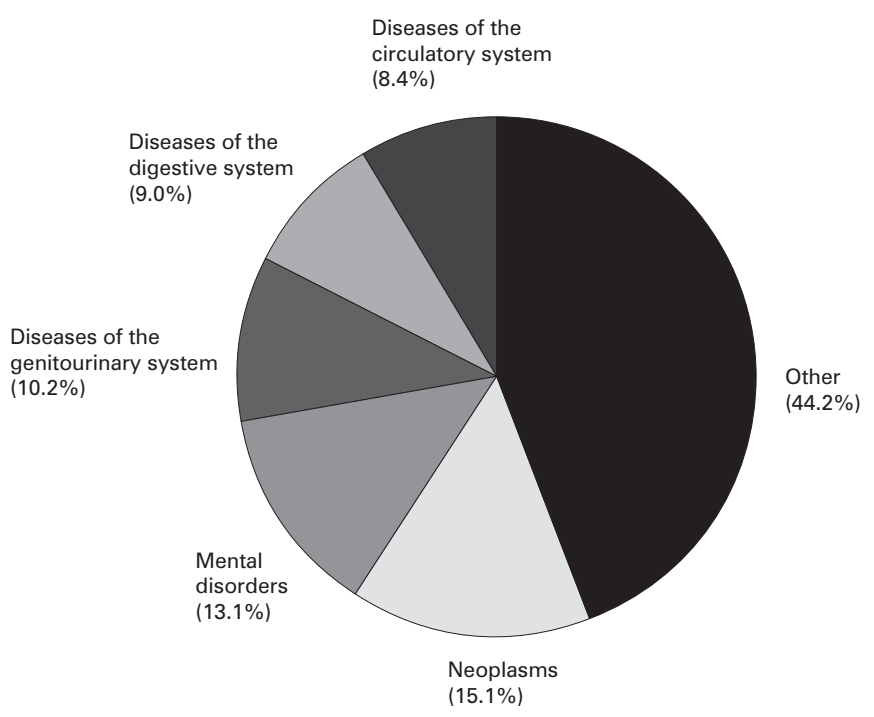

Fig. 1. Leading disease groups in hospital morbidity for the age group 20-59 years, Croatia, 2007. 
of psychiatric wards and hospitals also offer day programmes for patients with various diagnoses. Unfortunately, this has not facilitated the deinstitutionalisation of patients as it did in the USA and Europe. After hospital discharge, the majority of patients are treated as out-patients; they generally visit a psychiatrist once a month, or more frequently in psychotherapy sessions. Group psychodynamic psychotherapy, for patients with various diagnoses, including psychosis, is practised in the majority of psychiatric institutions.

There are a total of 3421 psychiatric beds in psychiatric hospitals, plus 426 in psychiatric wards in general hospitals and 428 in university psychiatric departments. The average duration of hospital treatment is $48.8,12.1$ and 17.0 days in these institutions, respectively (CNIPH, 2008).

There are very few rehabilitation and employment programmes for those with severe mental illness. The exceptions include initiatives at the Mental Health Centre and the Community Rehabilitation Centre in Zagreb, some hospitals with programmes for patients in a first episode of psychosis, self-help groups for patients and interventions for the involvement of patients' families in therapy and case management programmes (Gruber et al, 2006; Ivezic et al, 2009). There are several active user groups for persons who are severely mentally ill and people with addiction problems, which may be able to offer more comprehensive programmes on housing and employment in the near future.

Child and adolescent psychiatry (CAP) services lack both infrastructure (adequate centres and hospitals) and specialists. Preventive work in the field of mental health and mental health promotion was delegated to the National Programme for the Prevention and Treatment of Drug Addiction and the Croatian National Programme Against Stigma (CNIPH, 2008; Ivezic, 2002), but the latter was never applied (Ivezic, 2002).

Overall, there is poor collaboration between care providers at the three levels of healthcare. Unfortunately, one of the most comprehensive mental health programmes, which was supported by the majority of mental health policy makers, was never implemented (Croatian Psychiatric Association et al, 2001).

\section{Workforce issues}

In Croatia, there are currently 389 psychiatrists, 47 neuropsychiatrists and 105 psychiatric trainees. Psychiatrists work mainly in hospital in-patient and out-patient services. The few private psychiatrists in Croatia do not work additionally in the public health sector. Other mental health professionals include 1669 nurses, 130 psychologists, and 26 social workers and occupational therapists, working mainly in hospitals.

\section{Education}

The undergraduate medical programme is offered at four state medical schools; it lasts 6 years. After medical school and a 1-year internship, doctors obtain their licence by passing the state examination. Residency training usually follows. While waiting for a place on a residency programme, doctors usually work as GPs in specialised institutions or on scientific projects as research assistants. Postgraduate studies last 3 years.
Residency training in psychiatry follows the national programme developed by the Ministry of Health and Welfare. It lasts 4 years and comprises several parts: introduction (6 months), clinical psychiatry (18 months), alcoholism and addictions (3 months), psychological medicine (9 months), community psychiatry (5 months), forensic psychiatry (2 months), CAP (3 months) and neurology (3 months).

In two studies (Strkalj Ivezic et al, 2003; Rojnic Kuzman et al, 2009b), this programme was rated as generally unsatisfactory by the majority of residents. This is due to the lack of correlation between the training provided and the official programme outline, the inefficiency of the mentoring system, the lack of practical psychotherapy and funding issues. Together with training recommendations from the Union Européenne des Médecins Spécialistes (UEMS, European Union of Medical Specialists), these issues were addressed in the new residency training programme developed by an independent commission formed from representatives of the UEMS, academic staff and the Croatian Medical Chamber. This new programme was due to start in 2009.

To become a subspecialist, a psychiatrist enrols in subspecialty training, according to a programme designed by the CMHW. There are five subspecialties in Croatia: biological psychiatry; child and adolescent psychiatry; forensic psychiatry; psychotherapy; and social psychiatry. In addition, national psychiatric associations continually organise education for the subspecialties.

The ability of nurses to specialise in psychiatry during their undergraduate study represents an advancement of the education system for mental health professionals.

\section{Research and publications}

Croatian residents show an interest in science - about a third of them attend postdoctoral studies and publish scientific papers during their residency training (Fig. 2) (Rojnic Kuzman et al, 2009b). However, research activities are somewhat discouraged among residents; for example, the majority of residents rarely go abroad for scientific education. Also, the cost of doctoral studies is high compared with salaries (Rojnic Kuzman et al, 2009b).

Research projects in the field of mental health are mostly funded by the Ministry of Science, Education and Sport and recently by international funding sources. As judged by the type of ongoing scientific projects and published scientific papers, the main areas of psychiatric research in Croatia include addiction, war-related anxiety disorders and posttraumatic stress disorder, pharmacogenetics and genomics, suicidality, pharmacotherapy, neuroscience, education and social psychiatry.

There are two professional scientific journals in the field of mental health: Social Psychiatry and Psychiatria Danubina.

\section{International collaboration}

Croatia is an associate member of the UEMS Board and Section of Psychiatry. The Croatian Psychiatric Association is a regular member of the World Psychiatric Association (WPA). In addition, Croatian residents and young psychiatrists are 


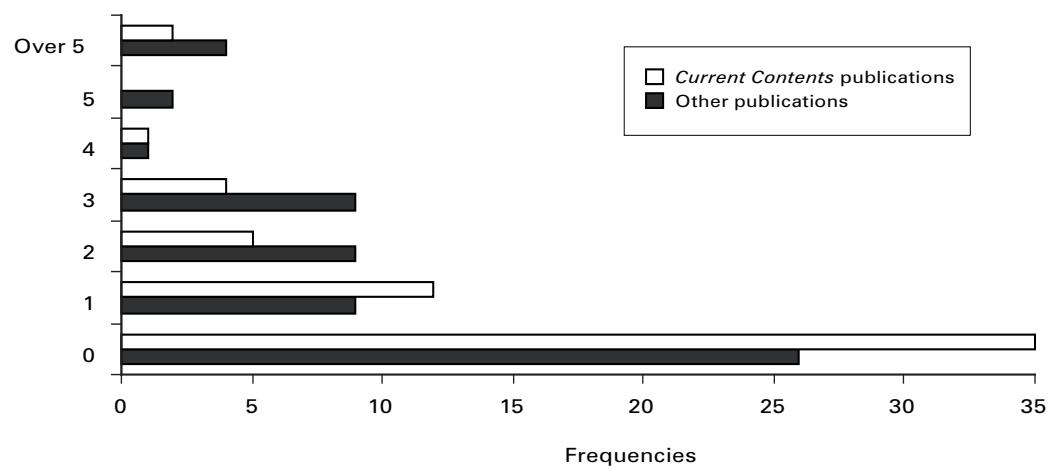

Fig. 2. Number of publications by Croatian residents, 2006 ( $n=66,89 \%$ of all psychiatric trainees in Croatia).

actively involved in the work of the European Federation of Psychiatric Trainees and thus the UEMS, and in the existing networks of young psychiatrists within the WPA and the European Psychiatric Association.

The World Health Organization (WHO) has an office in Zagreb. Croatia has a mental health representative in the WHO and collaborates with the WHO on many joint programmes, such the Stability Pact Initiative for the Development of Community Mental Health Centres, which resulted in the opening of the aforementioned Mental Health Centre and the Community Rehabilitation Centre in Zagreb.

On the other hand, few non-governmental organisations working in the field of mental health have participated in international programmes on stigma and human rights.

\section{Conclusion}

Despite the initiatives for the improvement of overall mental healthcare in Croatia in the past two decades, there is a need for organised mental health services in the community.

\section{Sources}

Naroden Novine (People's Newspaper) is the official gazette of the Republic of Croatia. The following are available in Croatian:

Zakon o zdravstvenoj zaštiti [Health care law]. Narodne Novine (2008), 150.
Plan i program mjera zdravstvene zaštite [Healthcare measure plan and programme]. Narodne Novine (2006), 126.

Zakon o obveznom zdravstvenom osiguranju [Obligatory health insurance law]. Narodne Novine (2008), 150.

Croatian National Institute of Public Health (2008) Croatian Health Service Yearbook 2007. CNIPH.

Croatian Psychiatric Association, Croatian Medical Association, Croatian Society for Clinical Psychiatry, Psychiatric Department, University of Illinois, USA (2001) Plan reorganizacije službe za mentalno zdravlje u $R H$. [The re-organization plan for the mental health services based on the model of community pychiatry.]

Gater, R., Jordanova, V., Maric, N., et al (2005) Pathways to psychiatric care in eastern Europe. British Journal of Psychiatry, 186, 529-535.

Gruber, E. N., Kajevic, M., Agius, M., et al (2006) Group psychotherapy for parents of patients with schizophrenia. International Journal of Social Psychiatry, 52, 487-500.

Ivezic, S. (2002) Nacionalni program borbe protiv stigme psihicke bolesti. 42. [National programme against the stigma associated with mental illnesses.] Medunarodni neuropsihijatrijski simpozij.

Ivezic, S., Muzinic, L. \& Vidulin, I. (2009) Program koordiniranog lijecenja (case managment) u rehabilitaciji osoba s psihoticnim poremecajem. [The program of coordinated treatment (case management) in the rehabiliation of people with psychotic disorders.] Socijalna psihijatrija (in press).

Rojnic Kuzman, M., Bolanca, M. \& Rojnic Palavra, I. (2009a) General practice meeting the needs for psychiatric care in Croatia. Psychiatria Danubina (in press).

Rojnic Kuzman, M., Jovanovic, N., Vidovic, D., et al (2009b) Problems in the current psychiatry residency training program in Croatia: residents' perspective. Collegium Antropologicum, 33, 217-223.

Strkalj Ivezic, S., Folnegovic Smalc, V. \& Bajs Bjegovic, M. (2003) Procjena programa specijalizacije iz psihijatrije [The evaluation of the psychiatry residency programme.] Lijec Vjesn, 125, 36-40.

\title{
Mental health services in Mexico
}

\section{Shoshana Berenzon, ${ }^{1}$ Héctor Sentíes ${ }^{2}$ and Elena Medina-Mora ${ }^{3}$}

\author{
${ }^{1}$ Researcher, National Institute of Psychiatry 'Ramon de la Fuente Muñíz', Mexico City \\ ${ }^{2}$ Education Director, National Institute of Psychiatry 'Ramon de la Fuente Muñiz', Mexico City \\ ${ }^{3}$ General Director, National Institute of Psychiatry 'Ramon de la Fuente Muñiz', Mexico City, email medinam@imp.edu.mx
}

$\mathrm{M}$ exico is a culturally, socially and economically heterogeneous country, with a population of over 100 million. Although it is regarded as a country with a mediumhigh income according to World Bank criteria, inequality continues to be one of its main problems. In addition to this, the country is going through a difficult period. Large parts of the population face economic insecurity, as a result of which feelings of despair, fear and impotence are common. It is hardly surprising, then, that mental disorders should constitute a major public health problem: depression is 